Article

\title{
Assessing the Role of Phosphorus as a Macropollutant in Four Typical Mediterranean Basin Soils
}

\author{
José Telo da Gama ${ }^{1,2, *}$, Luis Loures ${ }^{1,2}$ (D) António López-Piñeiro ${ }^{3}$ (D) and José Rato Nunes ${ }^{1,2}$ (D) \\ 1 VALORIZA-Research Centre for Endogenous Resource Valorization, 7300-110 Portalegre, Portugal; \\ lcloures@ipportalegre.pt (L.L.); ratonunes@ipportalegre.pt (J.R.N.) \\ 2 Polytechnic Institute of Portalegre (IPP), 7300-110 Portalegre, Portugal \\ 3 Área de Edafología y Química Agrícola, Facultad de Ciencias-IACYS, Universidad de Extremadura, Avda. de \\ Elvas s/n, 06071 Badajoz, Spain; pineiro@unex.es \\ * Correspondence: jose.gama@ipportalegre.pt; Tel.: +351-268-628-528
}

Citation: Telo da Gama, J.; Loures, L.; López-Piñeiro, A.; Nunes, J.R. Assessing the Role of Phosphorus as a Macropollutant in Four Typical Mediterranean Basin Soils. Sustainability 2021, 13, 10973. https:/ / doi.org/10.3390/su131910973

Academic Editor: Adriano Sofo

Received: 23 August 2021

Accepted: 29 September 2021

Published: 2 October 2021

Publisher's Note: MDPI stays neutral with regard to jurisdictional claims in published maps and institutional affiliations.

Copyright: (c) 2021 by the authors. Licensee MDPI, Basel, Switzerland. This article is an open access article distributed under the terms and conditions of the Creative Commons Attribution (CC BY) license (https:/ / creativecommons.org/licenses/by/ $4.0 /)$.

\begin{abstract}
Available phosphorus (AP) is a key macropollutant predictor of ecosystem services as well as a crucial indicator of soil productivity. Long-term applications of this macronutrient and its implications on sustainability in the face of peak phosphorus harvest have raised some concerns in recent years. This study aimed to characterise the edaphic AP in nearly 15,000 ha of the Mediterranean basin, an agricultural study area whose intensification is increasing with time. Four typical Mediterranean reference soil groups (RSG)—Calcisols, Luvisols, Fluvisols and Cambisols-were analysed and compared for their AP in two different agricultural settings—rain-fed and irrigation-from 2002 to 2012, where 1417 and 1451 topsoil samples were taken, respectively. AP increased from 2002 to 2012 in the irrigated Luvisols $(p<=0.05)$, Fluvisols $(p<=0.01)$ and Cambisols $(p<=0.05)$, while irrigated Calcisols maintained its concentrations $(p>0.05)$ over time. For rain-fed soils, the AP did not reveal significant differences in time for all RSG $(p>0.05)$. Additionally, irrigated Fluvisols and Cambisols presented $9 \%(p<=0.01)$ and 68\% $(p<=0.01)$ higher AP concentrations, respectively, than the corresponding rain-fed RSGs in 2012. We provide predictive maps for both 2002 and 2012. These results suggest that this area is departing from the sustainable goals of ecosystem services equilibrium; proper management practices that counteract the anthropogenic pressures in the area should be adopted.
\end{abstract}

Keywords: Mediterranean basin; available phosphorus; anthropic pressure; ecosystem services; degradation

\section{Introduction}

An increasing demand for resources in the finite planet Earth has promoted interest in the assessment and sustainable use of edaphic resources in agricultural settings. Anthropic pressures are largely contributing to ecosystem services' unsustainability, particularly in the Mediterranean basin [1,2], with increasing soil salinity, sodicity, alkalinity, loss of organic matter (SOM) content and accumulation of phytonutrients, especially ones that may cause disruption to ecosystem services. Nitrogen $(\mathrm{N})$ and phosphorus $(\mathrm{P})$, usually limiting factors in an agricultural setting, are such sustainability disruptors due to edaphic intensification, with increasing inputs of fertilisers, phytochemicals and irrigation water, in an overall setting of local climate changes (i.e., an increase in temperature and a decrease in precipitation) [3,4], which exposes the pragmatic importance of embracing sustainable agriculture approaches in the Mediterranean area [5-8]. It is curious, nonetheless, that the European statistics on the balance of $\mathrm{N}$ and $\mathrm{P}$ in agricultural soils point towards a decrease in nutrients in the soils and also in the consumption of inorganic $P$ fertilisers in the European Mediterranean basin countries [9,10]. On the other hand, authors such as Butusov and Jernelöv [11] state that the demand for P is increasing due to population growth and increased incomes in developing countries, resulting in a higher nutrition value of the new 
diet. Monteiro and Torent [12] state that the edaphic availability of $\mathrm{P}$ is fundamentally controlled by the equilibrium established between the phosphate concentration in the soil solid phase and its concentration in the soil solution (SS) and that European soils are saturated for $\mathrm{P}$ sorption due precisely to these high $\mathrm{P}$ concentrations in the SS. These concentrations are caused by anthropic $P$ inputs being far superior to their outputs over time creating a positive balance where $\mathrm{P}$ levels in the soil are higher than those required by the crops, and contributing to the elevated and continuous diffuse pollution caused by $\mathrm{N}$ and $P$ runoff and drainage.

The study of Yin et al. [13] states that the over-application of P fertilisers is adversely impacting ecosystem services and its sustainability; Butusov and Jernelöv [11] further this environmental impact alert and state that as long as water-soluble fertilisers are used for food production, between $10 \%$ and $30 \%$ of the deployed $\mathrm{P}$, in the medium term, will be removed from the productive soil layers by surface and groundwater runoffs. These authors also draw attention to the fact that agricultural runoff is the principal cause of eutrophication in inland and coastal waters and that none of the measures recommended by the European Union (EU) for environmental impact waste management practices can be recommended for implementation while these kinds of fertilisers are being used. In studies performed in the Mediterranean basin assessing phosphorus form fractions and the differences in dominant $P$ fractions between soil types, it was found that it is the phosphorus forms that dictate the edaphic $P$ release potential, that phosphate fertilisation increases the soil labile $\mathrm{P}$ fraction with, mostly, inorganic $\mathrm{P}$ and that it is its management, in combination with the soil's $\mathrm{pH}$ value, other ions in solution and other intrinsic soil properties that affect the relative distribution of adsorbed and precipitated P [14-16].

According to Carreira et al. [17], the main geochemical factor that controls the fixation of $\mathrm{P}$ in arid and semi-arid ecosystems is $\mathrm{CaCO}_{3}$, the leaching sequence resulting from the weathering of the bedrock in these ecosystems being $\mathrm{Ca}>\mathrm{Mg}>>>\mathrm{P}>\mathrm{Fe}>=\mathrm{Al}>\mathrm{Ti}$. In the typical Mediterranean calcareous soils, the low concentration of hydrogen phosphate in the soil solution is related to the adsorption surfaces, since in high concentrations, it precipitates mainly as calcium phosphate $[18,19]$ and Delgado and Torrent [14], in a study carried out on Spanish, Italian and German soils, conclude that the availability of $\mathrm{P}$ in calcareous soils is lower than that of non-calcareous soils, due to the fact that metallic phosphates (i.e., $\mathrm{Fe}, \mathrm{Al}$ and $\mathrm{Ca}$ phosphate) present in acid soils are more soluble than $\mathrm{Ca}$ phosphates in calcareous soils. In a study in Spanish calcareous soils, Borrero et al. [20] conclude that $\mathrm{P}$ sorption is significantly correlated with active and clay-sized $\mathrm{CaCO}_{3}$, but not with the total $\mathrm{CaCO}_{3}$.

This paper aims to improve knowledge on how available $\mathrm{P}$ concentrations vary between intensified and traditional agricultural systems in a study performed in an irrigation perimeter in four typical soils of a Mediterranean basin semi-arid region in real agricultural conditions (i.e., a non-controlled agricultural setting).

\section{Materials and Methods}

\subsection{Study Area}

The study was conducted in a Mediterranean basin field between the townships of Elvas and Campo Maior, Portugal, bordering Spain. The area is underlain by a combination of basic and hyperalkaline rocks. The area has a semi-arid environment according to the Thornthwaite climate classification system (DB2db4), with less than $500 \mathrm{~mm}$ of yearly precipitation and a mean annual evapotranspiration of approximately $813.2 \mathrm{~mm}$ [21]. This area includes the Caia irrigation perimeter where dozens of crops are present but the ones occupying the largest areas are: Olea europea L., Zea mays L., Lycopersicon esculentum Mill. and Allium sativum L. with a preponderance of $35 \%, 20 \%, 15 \%$ and $15 \%$, respectively. The study area has become more intensified since the start of this study, with crops such as intensive olive groves being substituted with super-intensive ones. Additionally, the use of irrigation water has been increasing since 2002, with an overall $55 \%$ average increase in water usage until 2017 (e.g., rice, olive groves, overall orchards, pasture and tomato have 
multiplied their water usage by 2, 3, 5, 5 and 2, respectively, from 2002 to 2017), which may be related to local climate changes [22]. For a better understanding of the crops present in the study area, please refer to Kaletová et al. [23]. The large crop variability associated with the different RSG, irrigation endowments, agricultural rotations and transitions, fertilisations, phytopharmaceuticals, etc., practiced in the irrigation perimeter does not allow us to describe them, except in the general terms presented here. The irrigation uses water of good quality, classified by the FAO classification system as C1S1 [24].

\subsection{Soil Data and Analysis}

A total of 1428 and 1451 topsoil samples were collected in 2002 and 2012, respectively. There are six main reference soil groups in the 15,000 ha that comprises the study area (Figure 1) where we studied the Luvisols, Cambisols, Fluvisols and Calcisols according to the FAO's World Reference Base [25]. A brief description of the dominant properties of the topsoil of these reference soil groups (RSG) for 2012 is presented in Table 1. Please refer to Telo da Gama et al. [21] for the 2002 edaphic description.

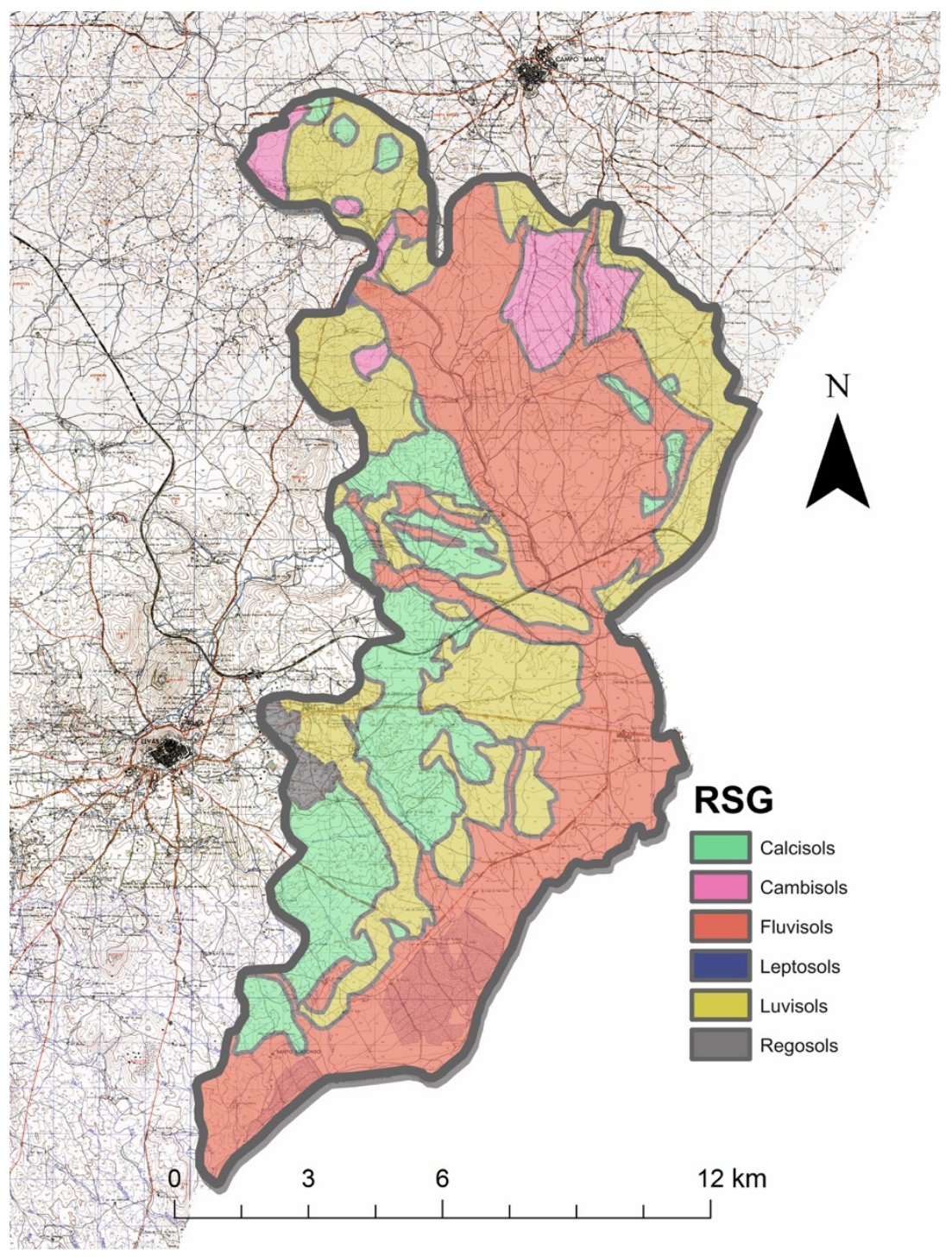

Figure 1. Soils of the study area according to FAOs classification system [25]. 
Table 1. Main edaphic properties of the study area soils for 2012.

\begin{tabular}{|c|c|c|c|c|c|c|c|c|c|c|c|c|c|}
\hline & & $\mathrm{pH}$ & SOM & EC & Sand & Silt & Clay & $\mathrm{Ca}$ & Mg & K & $\mathrm{Na}$ & CEC & BSP \\
\hline & $\begin{array}{c}\text { Depth } \\
\text { (cm) }\end{array}$ & (Water) & $(\%)$ & $\left(\mathrm{dS} \mathrm{m} \mathrm{m}^{-1}\right)$ & & $(\%)$ & & \multicolumn{6}{|c|}{$\left(\mathrm{cmol}_{(+)} \mathrm{kg}^{-1}\right)$} \\
\hline Fluvisols & & 6.59 & 1.22 & 157.1 & 72 & 13 & 15 & 8.26 & 2.13 & 0.40 & 0.17 & 21.6 & 49.3 \\
\hline Luvisols & 0 & 7.21 & 1.31 & 158.9 & 70 & 12 & 18 & 17.8 & 3.28 & 0.45 & 0.19 & 29.1 & 71.8 \\
\hline Calcisols & $0-20$ & 8.04 & 1.53 & 148.8 & 50 & 21 & 29 & 11.68 & 2.42 & 0.50 & 0.15 & 37.4 & 86.2 \\
\hline Cambisols & & 6.33 & 1.34 & 135.1 & 71 & 13 & 16 & 7.12 & 3.04 & 0.40 & 0.17 & 21.9 & 48.1 \\
\hline
\end{tabular}

pH: hydrogen potential; SOM: soil organic matter; EC: electrical conductivity; CEC: cation exchange capacity (1 M NH $4 \mathrm{OAc}$ at $\mathrm{pH} 7.0)$; $\mathrm{BSP}$ : base saturation percentage.

\subsection{Statistical analysis}

Soil samples were dried at room temperature, sieved through a $2 \mathrm{~mm}$ screen, and then analysed for their available phosphorus content, which was extracted with a buffered solution of ammonium lactate and acetic acid at $\mathrm{pH} 3.65-3.75$ [26]. They were then analysed by molecular absorption spectrophotometry at $650 \mathrm{~nm}$ in a UNICAM UV/VIS UV2 spectrophotometer after colour development, by adding a mixture of ammonium molybdate and ascorbic acid.

Statistical analyses were performed using the software package SPSS (v.25) where tests of normality (by Shapiro-Wilk) [27,28], inspection of kurtosis, skewness and standard errors [29-31] and visual inspection of the histograms, normal Q-Q plots and box plots were performed in the 2002 and 2012 sample data in order to assess if they were normally distributed. Tests for homogeneity of variances (Levene's) [32,33] were also performed in this subset in order to assess its homoscedasticity/heteroscedasticity. In the 2002 and 2012 sample data, we performed Independent Sample T-Tests on all normally distributed with homogeneity of variances data, and we applied the Central Limit Theorem when we had more than 30 samples per subgroup on our non-normally distributed, but with homogeneity of variances, data [34]. Data that showed non-normal distribution and with no homogeneity of variances were directly analysed by Mean Rank (MR) through the Mann-Whitney U Test $(\mathrm{U})$ or the Kruskal-Wallis H test $(\mathrm{H})$. All null hypotheses were rejected when $p<=0.05$. Geographic information system analysis was performed in ArcGIS v 10.5 software package and the predictive maps were created with an Ordinary Kriging interpolation, which was adjusted for a logarithmic factor equation and, when available, aided by ancillary variables [35-43]. Non-predictive maps were created with the software package QGIS 2.18.27 ‘Las Palmas’ [44].

\section{Results}

From the beginning of this study (2002) to 2012, generally, in the study area, there were no significant changes in the content of available $\mathrm{P}$ in the soil (Table $2 ; p>0.05$ ).

Table 2. Temporal evolution of the available $\mathrm{P}\left(\mathrm{mg} \mathrm{kg}^{-1}\right)$ in the study area from 2002 to 2012.

\begin{tabular}{cccccc}
\hline Parameter & Year & Mean & N & Test & $p$ \\
\hline \multirow{2}{*}{$\mathbf{P}\left(\mathbf{m g ~ k g}^{-\mathbf{1}}\right)$} & 2002 & 140 & 1308 & \multirow{2}{*}{$\mathrm{T}(2616):-4.056$} & 0.242 \\
\cline { 2 - 4 } & 2012 & 161 & 1310 &
\end{tabular}

P: Available phosphorus in the soil; T: Student's t test for two independent samples; $p$ : $p$ value.

While, in 2002, both agricultural systems presented the same available $P$ concentration $(p>0.05)$, the parameter showed significant differences $(p<=0.05)$ when rain-fed and irrigated agricultural systems were compared in 2012, with the average content of available $\mathrm{P}$ in the irrigation system registering $23.2 \%$ higher concentrations than the ones in the rain-fed system (Table 3). 
Table 3. Available P (mg kg $\left.{ }^{-1}\right)$ in rain-fed and irrigated agricultural system in 2002 and 2012.

\begin{tabular}{cccccccc}
\hline Parameter & Year & AS & Mean & N & Test & $p$ \\
\hline \multirow{2}{*}{$\mathbf{P}\left(\mathbf{m g ~ k g}^{-1}\right)$} & \multirow{2}{*}{2002} & Rain-fed & 143 & 631 & & U: $216,360.500$ & 0.685 \\
\cline { 2 - 5 } & & Irrigation & 139 & 677 & & \multirow{2}{*}{ U: $162,324.500$} & 0.000 \\
\cline { 2 - 5 } & \multirow{2}{*}{2012} & Rain-fed & 141 & 526 & & \\
\cline { 2 - 5 } & & Irrigation & 174 & 784 & & \\
\hline
\end{tabular}

P: Available phosphorus in the soil; CS: Agricultural system; U: Mann-Whitney U test; $p: p$ value.

A comparative analysis between the two agricultural systems, considering the four RSG (Table 4), shows that the content of available $\mathrm{P}$ was the same for both agricultural systems for all RSG in $2002(p>0.05)$, while, in 2012, it was significantly higher in the Fluvisols $(9.19 \% ; p<=0.05)$ and Cambisols $(68.3 \% ; p<=0.05)$ in the irrigated agricultural system than in the rain-fed. In Luvisols, the available P concentration for the irrigation agricultural system is at the acceptability threshold (Table 4, Figure 2a,b; $p=0.055$ ).

Table 4. Available $\mathrm{P}\left(\mathrm{mg} \mathrm{kg}^{-1}\right)$ in rain-fed and irrigated agricultural system in 2012 by reference soil group.

\begin{tabular}{|c|c|c|c|c|c|c|c|}
\hline Parameter & Year & RSG & AS & Mean & $\mathbf{N}$ & Test & $p$ \\
\hline \multirow{16}{*}{$P\left(\mathrm{mg} \mathrm{kg}^{-1}\right)$} & \multirow{8}{*}{2002} & \multirow{2}{*}{ Fluvisols } & Rain-fed & 136 & 222 & \multirow{2}{*}{ U: $44,455.500$} & \multirow{2}{*}{0.734} \\
\hline & & & Irrigation & 123 & 394 & & \\
\hline & & \multirow{2}{*}{ Luvisols } & Rain-fed & 144 & 194 & \multirow{2}{*}{$\mathrm{T}(352):-0.770$} & \multirow{2}{*}{0.442} \\
\hline & & & Irrigation & 173 & 160 & & \\
\hline & & \multirow{2}{*}{ Calcisols } & Rain-fed & 171 & 143 & \multirow{2}{*}{$\mathrm{T}(226):-0.177$} & \multirow{2}{*}{0.860} \\
\hline & & & Irrigation & 187 & 85 & & \\
\hline & & \multirow{2}{*}{ Cambisols } & Rain-fed & 100 & 61 & \multirow{2}{*}{$\mathrm{T}(95):-1.144$} & \multirow{2}{*}{0.255} \\
\hline & & & Irrigation & 77 & 36 & & \\
\hline & \multirow{8}{*}{2012} & \multirow{2}{*}{ Fluvisols } & Rain-fed & 144 & 198 & \multirow{2}{*}{$\mathrm{U}: 33,343.000$} & \multirow{2}{*}{0.000} \\
\hline & & & Irrigation & 157 & 430 & & \\
\hline & & \multirow{2}{*}{ Luvisols } & Rain-fed & 160 & 152 & \multirow{2}{*}{$\mathrm{T}(338): 1.928$} & \multirow{2}{*}{0.055} \\
\hline & & & Irrigation & 208 & 188 & & \\
\hline & & \multirow{2}{*}{ Calcisols } & Rain-fed & 156 & 99 & \multirow{2}{*}{$\mathrm{T}$ (227): 1.148} & \multirow{2}{*}{0.252} \\
\hline & & & Irrigation & 189 & 130 & & \\
\hline & & \multirow{2}{*}{ Cambisols } & Rain-fed & 87.6 & 64 & \multirow{2}{*}{ U: 692.000} & \multirow{2}{*}{0.001} \\
\hline & & & Irrigation & 147 & 36 & & \\
\hline
\end{tabular}

P: Available phosphorus in the soil; RSG: Reference soil group; CS: Agricultural system; U: Mann-Whitney U test; T: Student's t test for two independent samples; $p$ : $p$ value.

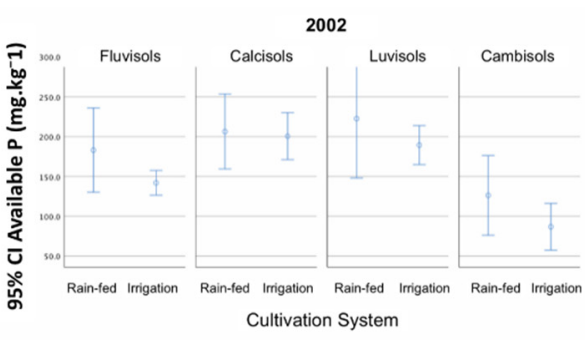

(a)

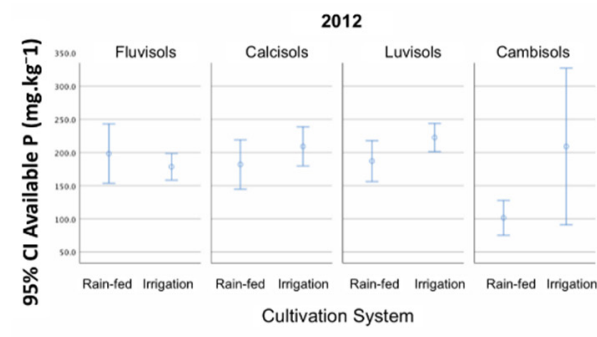

(b)

Figure 2. Error bar, by RSG, for available P ( $\left.\mathrm{mg} \mathrm{kg}^{-1}\right)$ in (a) 2002 and (b) 2012. 
Regarding the temporal evolution of the available $\mathrm{P}$ in the soils, for each agricultural system (Table 5), we conclude that, in the rain-fed system, the nutrients' edaphic concentration remained constant from 2002 to $2012(p>0.05)$, while, in the irrigated soils, there was a significant $25.0 \%$ increase $(p<=0.01)$.

Table 5. Available $\mathrm{P}\left(\mathrm{mg} \mathrm{kg}^{-1}\right)$ in rain-fed and irrigated agricultural system in 2012 by reference soil group.

\begin{tabular}{|c|c|c|c|c|c|c|c|c|c|c|c|}
\hline & \multirow{2}{*}{ Parameter } & \multirow{2}{*}{ Year } & \multirow{2}{*}{ RSG } & \multicolumn{4}{|c|}{ Rain-Fed } & \multicolumn{4}{|c|}{ Irrigation } \\
\hline & & & & Mean & $\mathbf{N}$ & Test & $p$ & Mean & $\mathbf{N}$ & Test & $p$ \\
\hline \multirow{2}{*}{ (a) } & \multirow{2}{*}{$\begin{array}{c}\mathrm{P} \\
\left(\mathrm{mg} \mathrm{kg}^{-1}\right)\end{array}$} & 2002 & \multirow{2}{*}{ Overall } & 143 & 631 & \multirow{2}{*}{$\mathrm{T}$ (1.155): 0.903} & \multirow{2}{*}{0.367} & 139 & 677 & \multirow{2}{*}{$\mathrm{T}(1.459):-4.027$} & \multirow{2}{*}{0.000} \\
\hline & & 2012 & & 141 & 526 & & & 174 & 784 & & \\
\hline \multirow{8}{*}{ (b) } & \multirow{8}{*}{$\begin{array}{c}\mathrm{P} \\
\left(\mathrm{mg} \mathrm{kg}^{-1}\right)\end{array}$} & 2002 & \multirow{2}{*}{ Fluvisols } & 136 & 222 & \multirow{2}{*}{$\mathrm{T}(418):-0.427$} & \multirow{2}{*}{0.670} & 123 & 394 & \multirow{2}{*}{$\mathrm{T}(418):-0.427$} & \multirow{2}{*}{0.005} \\
\hline & & 2012 & & 144 & 198 & & & 157 & 430 & & \\
\hline & & 2002 & \multirow{2}{*}{ Luvisols } & 144 & 194 & \multirow{2}{*}{$\mathrm{T}(344): 0.793$} & \multirow{2}{*}{0.428} & 173 & 160 & \multirow{2}{*}{$\mathrm{T}(346):-2.032$} & \multirow{2}{*}{0.043} \\
\hline & & 2012 & & 160 & 152 & & & 208 & 188 & & \\
\hline & & 2002 & \multirow{2}{*}{ Calcisols } & 171 & 143 & \multirow{2}{*}{$\mathrm{T}(240): 0.751$} & \multirow{2}{*}{0.454} & 187 & 85 & \multirow{2}{*}{$\mathrm{T}(213):-0.388$} & \multirow{2}{*}{0.698} \\
\hline & & 2012 & & 156 & 99 & & & 189 & 130 & & \\
\hline & & 2002 & \multirow{2}{*}{ Cambisols } & 100 & 61 & \multirow{2}{*}{$\mathrm{T}(123): 0.893$} & \multirow{2}{*}{0.374} & 76.9 & 36 & \multirow{2}{*}{$\mathrm{T}(70):-2.042$} & \multirow{2}{*}{0.045} \\
\hline & & 2012 & & 87.6 & 64 & & & 147 & 36 & & \\
\hline
\end{tabular}

P: Available phosphorus in the soil; RSG: Reference soil group; T: Student's t test for two independent samples; $p$ : $p$ value.

A more detailed analysis (Table 5) reveals that the accumulation of available P occurred for all RSG under irrigation except for Calcisols $(p>0.05)$, increasing its content by 27.7 $(p<=0.01), 20.7(p<=0.05)$ and 91.7\% $(p<=0.05)$, in Fluvisols, Luvisols and Cambisols, respectively.

From the analysis of Table 6, we conclude that the surface area with an available $\mathrm{P}$ concentration above $100 \mathrm{mg} \mathrm{kg}^{-1}$ increased by $29.9 \%$. In 2002, the "above $100 \mathrm{mg} \mathrm{kg}^{-1}$ range already represented $66.9 \%$ of the soils in the study area and, in 2012, it represented $86.9 \%$. From 2002 to 2012, there was a $261 \%$ increase in the area, with available P levels higher than $200 \mathrm{mg} \mathrm{kg}^{-1}$. A comparison of Tables 4 and 6 reveals that only the average crops on rain-fed Cambisols could experience increases in their yields using P fertilisation.

Table 6. Fertility class classification according to the content of available $P$ in the soil [45] and the corresponding crop response. Available P for 2002 and 2012 in the study area.

\begin{tabular}{ccccccc}
\hline \multirow{2}{*}{$\mathbf{P}\left(\mathbf{m g ~ k g}^{-\mathbf{1})}\right.$} & \multirow{2}{*}{ Fertility Class } & \multirow{2}{*}{ Crop Response } & \multicolumn{2}{c}{$\mathbf{2 0 0 2}$} & \multicolumn{2}{c}{$\mathbf{2 0 1 2}$} \\
\cline { 4 - 7 } & & & Area (ha) & $\mathbf{\%}$ & Area (ha) & $\mathbf{\%}$ \\
\hline$<25$ & Very low & $<50 \%$ & 4.70 & 0.000 & 1.50 & 0.000 \\
$25-50$ & Low & {$[50-75 \%]$} & 672 & 4.40 & 131 & 0.900 \\
$50-100$ & Medium & {$[75-95 \%]$} & 4337 & 28.6 & 1860 & 12.3 \\
$100-200$ & High & {$[95-99]$} & 8825 & 58.2 & 8396 & 55.4 \\
$>200$ & Very high & $>99 \%$ & 1319 & 8.70 & 4770 & 31.5 \\
\hline
\end{tabular}

The analysis of Figure $3 \mathrm{a}, \mathrm{b}$ clearly shows that the increase detected in the available $\mathrm{P}$ concentration also occupies most of the study area. It should also be noted that only the crops grown on $13.2 \%$ of the total study surface (i.e., with soils with less than $100 \mathrm{mg} \mathrm{kg}^{-1}$ of available $\mathrm{P}$ ) would respond to fertilisation with $\mathrm{P}$ for most crops. 


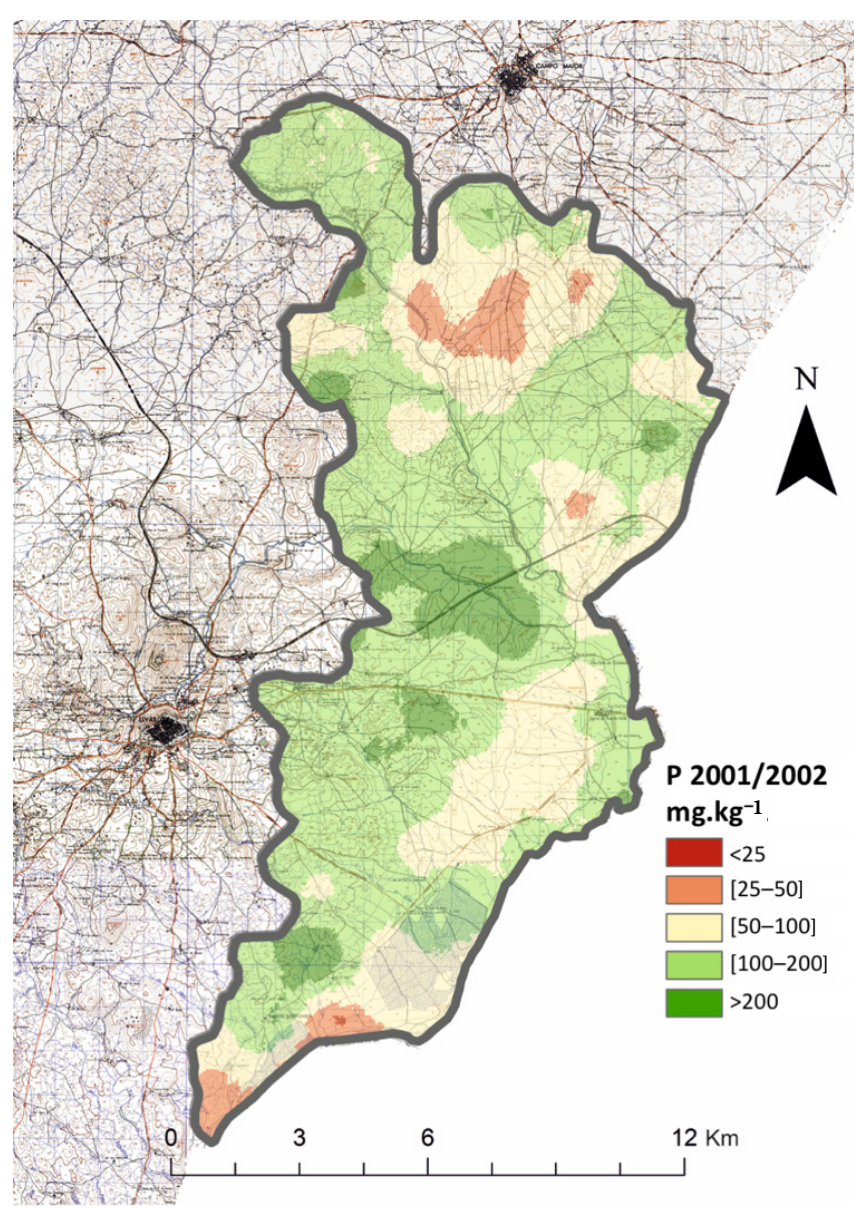

(a)

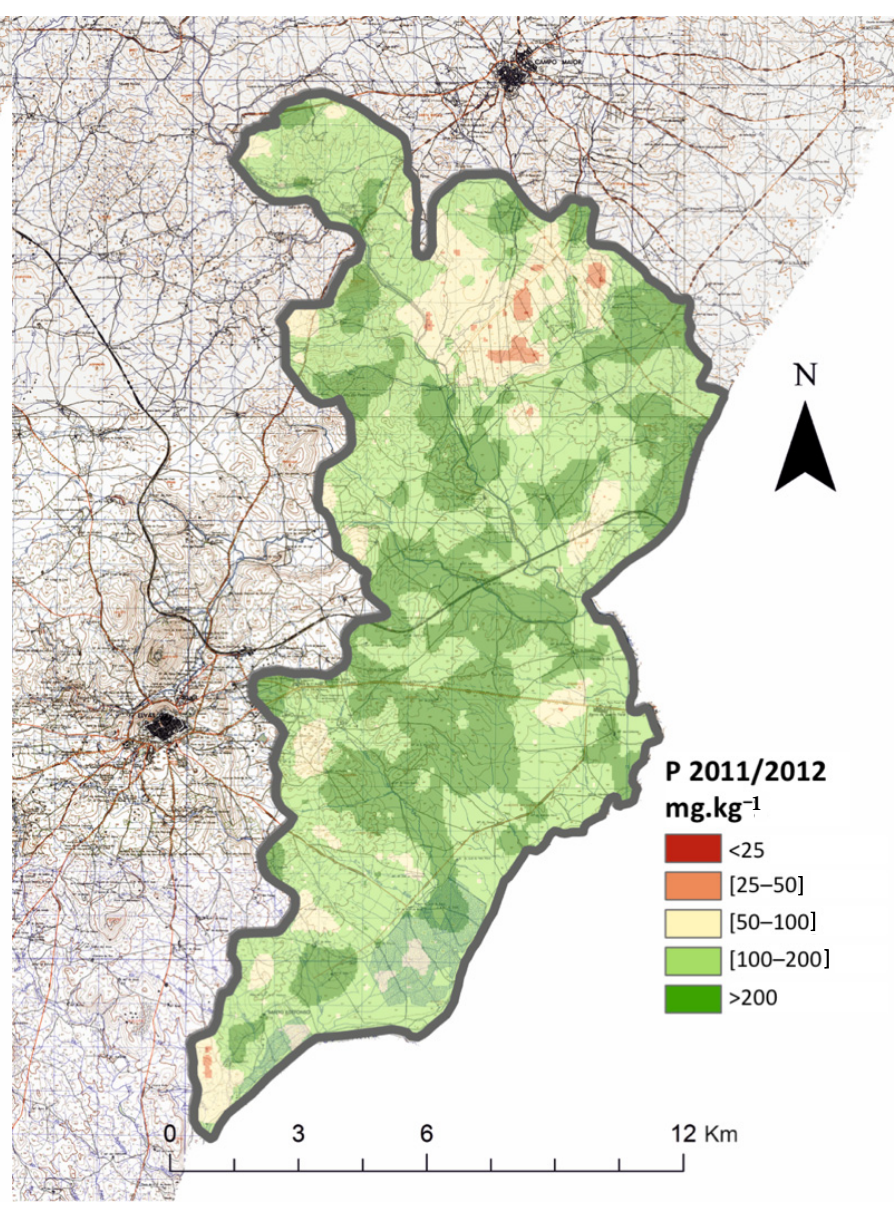

(b)

Figure 3. Available P content (mg kg-1) in the study area for (a) 2002 and (b) 2012.

\section{Discussion}

Although no overall significant differences in available P were detected from 2002 to 2012 and while, in 2002, the available P concentration did not differ between the rainfed cultivation system and the irrigation system, we registered a significantly greater concentration in irrigated soils than in rain-fed soils in 2012. This revealed the increased use of this macronutrient since 2002 in irrigated agricultural systems (e.g., through phosphate fertilisation or organic P amendments), increasing the labile fraction of $\mathrm{P}$ in the soils, which is in accordance with the study of Monteiro and Torent [12]. This intensification from 2002 to 2012 is more obvious when we compare both cultivation systems by RSG in both sampled years. While, in 2002, the available P concentration was the same in both agricultural systems for a particular RSG, in 2012, the Fluvisols and Cambisols revealed greater phosphorus concentrations due to the fact that this element is a key macronutrient and, therefore, its excessive use is a common practice in the irrigated system since it is mainly is applied in fertilisation systems in the form of NPK. Because the Fluvisols are an RSG that is closer to the rivers and irrigation points that feed the irrigation system, they are the soils that have been under irrigation for the most time (i.e., some have been under irrigation since 1969) and where cash crops are being grown. As stated in Telo da Gama et al. (2019), the Cambisols of the study area recently underwent an intensification that made for a $68.3 \%$ increase in available $\mathrm{P}$ (and also an increase in available $\mathrm{K}$ of $37 \%$ in the same period). The fact that Calcisols present no significant differences in available $\mathrm{P}$ concentrations between both agricultural systems may be attributed to the tendency that phosphorus has to precipitate with the $\mathrm{Ca}^{2+}$ ion, an element highly available in these soils, diminishing its solubility over time as the phosphorus continues to react with the 
available $\mathrm{Ca}^{2+}$ in the soil (i.e., initially forming monocalcium phosphate $\left(\mathrm{Ca}\left(\mathrm{H}_{2} \mathrm{PO}_{4}\right)_{2}\right)$, later, dicalcium phosphate $\left(\mathrm{CaHPO}_{4}\right)$ and, finally, tricalcium phosphate, $\left.\mathrm{Ca}_{3}\left(\mathrm{PO}_{4}\right)_{2}\right)$, which is demonstrated in the study by Carreira et al. [17].

The fact that, over time, there was no statistical difference in rain-fed soils is probably due to the more sustainable mode of production of this agricultural system and its balance between the inputs and outputs of the nutrients, especially when compared with the irrigated system that demonstrates an excessive use of phosphorus as a fertiliser in this cropping system. Therefore, over time, all RSGs except for Calcisols revealed an increase in available $\mathrm{P}$ in the irrigated agricultural system. The fact that the available P levels remained constant in the RSG Calcisols agrees with the results of most of the authors consulted $[13,14,17,20]$, these data serving to reinforce the aforementioned proposition. Once again, we notice a greater rise in parameters in the RSG Cambisols in relation to the other RSG, where the available P almost doubled from 2002 to 2012, revealing the recent intensification that is taking place in these soils in their conversion from rain-fed to irrigated fields [21].

As for the fertility classes according to the edaphic available P content (Egnér Riehm), this table considers an average crop (adapted from the official Portuguese fertilisation manual [45]) and that the available P is the limiting factor of the crop (e.g., an available $\mathrm{P}$ concentration of $44 \mathrm{mg} \mathrm{kg}^{-1}$ falls in the Low fertility class, which means that the crop productivity response will fall between $50 \%$ and $75 \%$ of the crop genetic capacity). In the results section, we showed that only the average crops on rain-fed Cambisols could experience increases in their yields using P fertilisation because of their "Medium" classification, meaning that, ceteris paribus, the crop could eventually express merely $75 \%$ of its total genetic potential and thus, phosphorus applications make agricultural sense. The remaining RSGs, regardless of the cultivation system, are in a high or very high fertilisation class, where the content of available $P$ in the soils would allow most of the crops to express a minimum of $95 \%$ of their genetic potential, indicating that the response of the average crop to phosphorus fertilisation would be minimal to non-existent. In these cases, if fertilisation is to be carried out, it should be with the goal of nutrient maintenance in the soil only; this is not the case in the study area as there was a $261 \%$ increase in available P levels above the very high class (i.e., above the $200 \mathrm{mg} \mathrm{kg}^{-1}$ where the genetic response of most crops is at a minimum of $99 \%$ ). This result is not surprising since this is a nutrient that is frequently incorporated into agricultural soils in the form of NPK fertilisers, causing the specific and spatial variation registered in its contents to be motivated by agricultural practice. This surplus of available $P$ could enhance the leaching of this element, contributing, together with $\mathrm{N}$, to water eutrophication [45].

\section{Conclusions}

This multi-year study's findings demonstrated that intensification through irrigation in this 15,000 ha Mediterranean basin field has a tendency towards the accumulation of available $\mathrm{P}$ in Fluvisols, Luvisols and Cambisols. The presence of available $\mathrm{Ca}^{2+}$ may have contributed to the observed equilibrium in available $\mathrm{P}$ in rain-fed and irrigated agricultural systems in Calcisols, as these soils are naturally rich in calcium. In contrast, all non-intensified soils maintained their edaphic available $P$, pointing to the overall greater sustainability of this agricultural system. Not surprisingly, the soils nearer the rivers and irrigation points, which have been under irrigation for the most time, or the ones that were recently intensified (e.g., converted from a rain-fed to irrigated agricultural system), are the ones that present the greatest increases in available $\mathrm{P}$, enhancing the leaching of this element and contributing to water eutrophication. These results are but one more account of the anthropological impact on ecosystem services that is jeopardising its sustainability and proper conservation and could contribute to better land use.

Author Contributions: Conceptualization, J.R.N., L.L. and A.L.P.; methodology, J.R.N., L.L. and A.L.P.; software, J.T.d.G; validation, J.T.d.G; formal analysis, J.T.d.G; investigation, J.T.d.G, J.R.N., L.L. and A.L.P.; resources, J.R.N., L.L. and A.L.P.; data curation, J.T.d.G; writing-Original draft 
preparation, J.T.d.G; writing-Review and editing, J.T.d.G, J.R.N., L.L. and A.L.P; visualization, J.T.d.G, J.R.N., L.L. and A.L.P.; supervision, J.R.N., L.L. and A.L.P.; project administration, J.R.N.; funding acquisition, J.R.N. and L.L. All authors have read and agreed to the published version of the manuscript.

Funding: This research was funded by national funds through the Fundação para a Ciência e a Tecnologia, I.P. (Portuguese Foundation for Science and Technology) by the project UIDB/05064/2020 (VALORIZA-Research Centre for Endogenous Resource Valorization). Support for this work was provided by the Spanish Ministry of Science, Innovation and Universities (RTI2018-095461-B-I00), and by the Extremadura Regional Government (GR18011; IB16075) with co-financing from the Fondo Europeo de Desarrollo Regional.

Institutional Review Board Statement: Not applicable.

Informed Consent Statement: Not applicable.

Data Availability Statement: Not applicable.

Acknowledgments: The authors would like to express their gratitude to the 'Caia Beneficiaries Association', a non-profit organization under the supervision of the Portuguese Ministry of Agriculture and which is in charge of the management, exploitation, and conservation of the Caia Hydro-agriculture Project and Irrigation Perimeter for the administrative support and data provided.

Conflicts of Interest: The authors declare no conflict of interest. The funders had no role in the design of the study; in the collection, analyses, or interpretation of data; in the writing of the manuscript, or in the decision to publish the results.

\section{References}

1. Loures, L.; Gama, J.; Nunes, J.; Lopez-Piñeiro, A. Assessing the Sodium Exchange Capacity in Rainfed and Irrigated Soils in the Mediterranean Basin Using GIS. Sustainability 2017, 9, 405. [CrossRef]

2. Azimi Sardari, M.R.; Bazrafshan, O.; Panagopoulos, T.; Sardooi, E.R. Modeling the Impact of Climate Change and Land Use Change Scenarios on Soil Erosion at the Minab Dam Watershed. Sustainability 2019, 11, 3353. [CrossRef]

3. Guiot, J.; Cramer, W. Climate change: The 2015 Paris Agreement thresholds and Mediterranean basin ecosystems. Science 2016, 354, 465-468. [CrossRef] [PubMed]

4. Vozinaki, A.-E.K.; Tapoglou, E.; Tsanis, I.K. Hydrometeorological impact of climate change in two Mediterranean basins. Int. J. River Basin Manag. 2018, 16, 245-257. [CrossRef]

5. Stagnari, F.; Maggio, A.; Galieni, A.; Pisante, M. Multiple benefits of legumes for agriculture sustainability: An overview. Chem. Biol. Technol. Agric. 2017, 4, 2. [CrossRef]

6. Pagnani, G.; Pellegrini, M.; Galieni, A.; D’Egidio, S.; Matteucci, F.; Ricci, A.; Stagnari, F.; Sergi, M.; Sterzo, C.L.; Pisante, M.; et al. Plant growth-promoting rhizobacteria (PGPR) in Cannabis sativa 'Finola' cultivation: An alternative fertilization strategy to improve plant growth and quality characteristics. Ind. Crop. Prod. 2018, 123, 75-83. [CrossRef]

7. Farooq, M.; Rehman, A.; Pisante, M. Sustainable Agriculture and Food Security. In Innovations in Sustainable Agriculture; Farooq, M., Pisante, M., Eds.; Springer: Cham, Switzerland, 2019; pp. 3-24. Available online: http:/ /link.springer.com/10.1007/978-3-03 0-23169-9_1 (accessed on 5 July 2021).

8. Naranjo Gómez, J.M.; Lousada, S.; Garrido Velarde, J.G.; Castanho, R.A.; Loures, L. Land-Use Changes in the Canary Archipelago Using the CORINE Data: A Retrospective Analysis. Land 2020, 17, 232. [CrossRef]

9. Radermacher, W.; Johansson, A.; Lang, V. Europe in Figures: Eurostat Yearbook 2012; Renouf Publishing Company Limited: Ogdensburg, NY, USA, 2013; Volume 6.

10. Eurostat-Data Explorer. Available online: https:/ / ec.europa.eu/eurostat/web/main/data/database (accessed on 7 July 2021 ).

11. Butusov, M.M.; Jernelöv, A. Phosphorus: An Element That Could Have Been Called Lucifer; Springer: New York, NY, USA, 2013; p. 106.

12. Monteiro, M.C.H.; Torent, J. Dinâmica do Fósforo no Solo: Perspectiva Agronómica e Ambiental; IPCB: Castelo Branco, Portugal, 2010; p. 97, ISBN 978-989-8196-10-1.

13. Yin, Z.; Fan, B.; Roberts, D.P.; Chen, S.; Shi, F.; Buyer, J.S.; Jiang, H. Enhancement of maize growth and alteration of the rhizosphere microbial community by phosphate-solubilizing fungus Aspergillus aculeatus P93. J. Agric. Biotechnol. 2017, 2, 10.

14. Delgado, A.; Torrent, J. Phosphorus Forms and Desorption Patterns in Heavily Fertilized Calcareous and Limed Acid Soils. Soil Sci. Soc. Am. J. 2000, 64, 2031. [CrossRef]

15. Saavedra, C.; Delgado, A. Phosphorus Fractions and Release Patterns in Typical Mediterranean Soils. Soil Sci. Soc. Am. J. 2005, 69, 607. [CrossRef]

16. Devau, N.; Cadre, E.L.; Hinsinger, P.; Jaillard, B.; Gérard, F. Soil pH controls the environmental availability of phosphorus: Experimental and mechanistic modelling approaches. Appl. Geochem. 2009, 24, 2163-2174. [CrossRef] 
17. Carreira, J.; Lajtha, K.; Niell, X. Phosphorus transformations along a soil/vegetation series of fire-prone, dolomitic, semi-arid shrublands of southern Spain Soil P and Mediterranean shrubland dynamic. Biogeochemistry 1997, 39, 87-120. [CrossRef]

18. De la Peña-Lastra, S.; Affre, L.; Otero, X.L. Soil nutrient dynamics in colonies of the yellow-legged seagull (Larus michahellis) in different biogeographical zones. Geoderma 2020, 361, 114109. [CrossRef]

19. Makttoof, E.A.; Kassim, J.K.; Khuzale, K.H. Distribution of different forms of phosphorus in calcareous soils from middle and south of Iraq. Al-Qadisiyah J. Agric. Sci. 2020, 10, 293-303.

20. Borrero, C.; Peña, F.; Torrent, J. Phosphate sorption by calcium carbonate in some soils of the Mediterranean part of Spain. Geoderma 1988, 42, 261-269. [CrossRef]

21. Telo da Gama, J.; Rato Nunes, J.; Loures, L.; Lopez Piñeiro, A.; Vivas, P. Assessing Spatial and Temporal Variability for Some Edaphic Characteristics of Mediterranean Rainfed and Irrigated Soils. Agronomy 2019, 9, 132. [CrossRef]

22. Telo da Gama, J.; Loures, L.; Lopez-Piñeiro, A.; Quintino, D.; Ferreira, P.; Nunes, J.R. Assessing the Long-Term Impact of Traditional Agriculture and the Mid-Term Impact of Intensification in Face of Local Climatic Changes. Agriculture 2021, 11, 814. [CrossRef]

23. Kaletová, T.; Loures, L.; Castanho, R.A.; Aydin, E.; da Gama, J.T.; Loures, A.; Truchy, A. Relevance of Intermittent Rivers and Streams in Agricultural Landscape and Their Impact on Provided Ecosystem Services-A Mediterranean Case Study. IJERPH 2019, 16, 2693. [CrossRef]

24. Nunes, J. Los suelos del perimetro regable del Caia (Portugal): Tipos, fertilidad e impacto del riego en sus propriedades químicas. Ph.D Thesis, Universidad de Extremadura, Badajoz, Spain, 2003.

25. FAO. World Reference Base for Soil Resources 2014: International Soil Classification System for Naming Soils and Creating Legends for Soil Maps; FAO: Rome, Italy, 2014.

26. Egnér, H.; Riehm, H.; Domingo, W.R. Investigations on chemical soil analysis as the basis for estimating soil fertility. II. Chem. Extr. Methods Phosphorus Potassium Determ. K. Lantbr. Ann. 1960, 26, 199-215.

27. Shapiro, S.S.; Wilk, M.B. An Analysis of Variance Test for Normality (Complete Samples). Biometrika 1965, 52, 591. [CrossRef]

28. Razali, N.M.; Wah, Y.B. Power comparisons of shapiro-wilk, kolmogorov-smirnov, lilliefors and anderson-darling tests. J. Stat. Modeling Anal. 2011, 2, 21-33.

29. Cramer, D. Fundamental Statistics for Social Research: Step-by-step Calculations and Computer Techniques Using SPSS for Windows; Routledge: London, UK, 2003.

30. Cramer, D.; Howitt, D.L. The Sage Dictionary of Statistics: A Practical Resource for Students in the Social Sciences; Sage: Thousand Oaks, CA, USA, 2004.

31. Doane, D.P.; Seward, L.E. Measuring skewness: A forgotten statistic? J. Stat. Educ. 2011, 19, 6. [CrossRef]

32. Nordstokke, D.W.; Zumbo, B.D. A new nonparametric Levene test for equal variances. Psicol. Int. J. Methodol. Exp. Psychol. 2010, $31,401-430$.

33. Nordstokke, D.W.; Zumbo, B.D.; Cairns, S.L.; Saklofske, D.H. The operating characteristics of the nonparametric Levene test for equal variances with assessment and evaluation data. Pract. Assess. Res. Evaluation 2011, 16, 5.

34. Fischer, H. A History of the Central Limit Theorem: From Classical to Modern Probability Theory; Springer: New York, NY, USA; London, UK, 2011; p. 402.

35. Hengl, T.; Heuvelink, G.B.M.; Stein, A. A generic framework for spatial prediction of soil variables based on regression-kriging. Geoderma 2004, 120, 75-93. [CrossRef]

36. Baxter, S.J.; Oliver, M.A. The spatial prediction of soil mineral N and potentially available N using elevation. Geoderma 2005, 128, 325-339. [CrossRef]

37. Inácio, M.; Pereira, V.; Pinto, M. The Soil Geochemical Atlas of Portugal: Overview and applications. J. Geochem. Explor. 2008, 98, 22-33. [CrossRef]

38. Li, Y. Can the spatial prediction of soil organic matter contents at various sampling scales be improved by using regression kriging with auxiliary information? Geoderma 2010, 159, 63-75. [CrossRef]

39. Sun, W.; Minasny, B.; McBratney, A. Analysis and prediction of soil properties using local regression-kriging. Geoderma 2012, 171, 16-23. [CrossRef]

40. Behera, S.K.; Shukla, A.K. Spatial Distribution of Surface Soil Acidity, Electrical Conductivity, Soil Organic Carbon Content and Exchangeable Potassium, Calcium and Magnesium in Some Cropped Acid Soils of India. Land Degrad. Dev. 2015, 26, 71-79. [CrossRef]

41. Chen, T.; Chang, Q.; Liu, J.; Clevers, J.G.P.W.; Kooistra, L. Identification of soil heavy metal sources and improvement in spatial mapping based on soil spectral information: A case study in northwest China. Sci. Total. Environ. 2016, 565, 155-164. [CrossRef]

42. Hou, D.; O'Connor, D.; Nathanail, P.; Tian, L.; Ma, Y. Integrated GIS and multivariate statistical analysis for regional scale assessment of heavy metal soil contamination: A critical review. Environ. Pollut. 2017, 231, 1188-1200. [CrossRef]

43. Tziachris, P.; Metaxa, E.; Papadopoulos, F.; Papadopoulou, M. Spatial Modelling and Prediction Assessment of Soil Iron Using Kriging Interpolation with $\mathrm{pH}$ as Auxiliary Information. Isprs Int. J. Geo-Inf. 2017, 6, 283. [CrossRef]

44. Team, Q.D. QGIS geographic information system. Open Source Geospat. Found. Proj 2015.

45. INIAP. Manual de Fertilização das Culturas; Laboratório Químico Agrícola Rebelo da Silva: Lisboa, Portugal, 2006. 